\title{
Work in Prisons: The Gender Difference that Intensifies with the Incarceration and Indicates the Lack of Human Dignity
}

\author{
Lorena Carvalho Leite Garcia de Oliveira* \\ Universidade Federal do Oeste da Bahia \\ 425 Teixeira de Freitas Street, Barreiras 47806120, Brasil
}

\begin{abstract}
This study deals with gender inequality in the labour market, a situation that becomes worse when we talk about incarcerated women, showing the lack of human dignity in the prision system. Women's participation in the labour market has increased over the years, but the gender difference is noticeable when we analyze the positions held and the pay gap. In the penitentiary system, situation is reversed, the number of incarcerated women who work is higher compared to men, and however the conditions referring to human dignity when we speak about gender are unconstitutional. The scope of this article is to lead to academic debate the issue of dignity of incarcerated women in labour market, since the prision system aggravates and indicates the gender difference. To archive the research purpose, the methodology used will be bibliographic and documentary, bringing the concept of work, the discussion about acquisition of the right to work for women and the analysis of data from the profile of incarcerated women, access to work and education in the prison environment. With a population of 37.828 women in spaces designed for men it is necessary think about work, as fundamental at re-socializing and at human dignity.
\end{abstract}

Keywords: Women; Prison; Work; Human dignity.

DOI: $10.7176 /$ RHSS/11-11-12

Publication date:June $30^{\text {th }} 2021$

\section{Introduction}

According to Coutinho (as cited in Martinez 2020, p.52) the expression "work" originated from Latin tripalium, as well as the expression lavoro in Italian, labour of English origin and ponos in Greek, were linked the meaning of pain, suffering, fatigue and painful activity. With the development of first way of work that was slavery to paid employment with rights, now has attribute of human dignity and fundamental right.

The woman didn't have legal protection in labour market and even though plentiful supply of cheap labor, there was prejudice resulting from morality that condemned the woman who didn't dedicated to domestic chores. In 1991 the International Labour Organization(ILO) impose the conventions three and four which addresses about night-shift work and maternity leave, subsequently enacted by Brazil.

Nationally, the full achievement of the right to decent work arises with the Consolidação das Leis do Trabalho (CLT) that in his chapter III provides for protection of women's work (Law n. 5.452, 1943). In addition, the Constitution of the Federative Republic of Brazil (1988) provides for right to maternity leave and stability for the pregnant woman, prohibition the wage gap, exercise of functions and admission criteria based on gender.

According to Estatística de Gênero: indicadores sociais das mulheres no Brasil (Instituto Brasileiro de Geografia e Estatística[IBGE],2010), women's participation in labour markets tripled over the years, but receive $75 \%$ of men's wages and occupy about $39,1 \%$ of management positions. While the men's received an average of $\mathrm{R} \$ 2.495,00$, in the final quarter of 2016, the women received R\$ 1.958, 00, income 22\% lower (Pesquisa Nacional por Amostra de Domicilios [PNAD], 2019). In addition, among workers with higher education, the difference is even more, climbing to $38 \%$. They had an average salary of $\mathrm{R} \$ 6.292,00$, and women $\$ 3.876,00$.

Access of work for women out of prisions suffer with gender difference, which is noticeable when we comparing wages, and we don't speak about lack of education, since the percentage of women with higher education is higher. According to the Índice de Desenvolvimento de Gênero released by United Nations Development Programme (UNDP) in 2019, women in Brazil are in better health and education, having more year of schooling, higher average years of study, but receive $41,5 \%$ less than men.

Situation in the penitentiary system is reverse, the number of incarcerated women who work is higher compared to men, but the specificities related to gender in prisons added to the profile of incarcerated women aggravate the lack of human dignity in the exercise of work and the resocialization.

It is in this context that the article develops, through the discussion of concepts of work, dignity and resocialization, which are intrinsically interconnect to development of the person deprived of liberty. Prison system indicates the gender difference that is not considered before the physical structure, the provision of education, health, work and has a consequence the worsening of gender difference and lack of human dignity.

Through the clash of concepts brought, the scope of this article is to lead to academic debate the issue of dignity of incarcerated women in labour market, since the prison system aggravates and indicates the gender 
difference. In addition, it seeks to highlight violation of the right to work and, therefore, resocialization.

This research is structured in two parts. The first part search conceptualize work, dignity and resocialization, as they are interlinked concepts that corroborate with the importance of work institute when we talk about former convicts of the prision system. The second part brings the contextualization of female prison environment, highlights the lack of human dignity that reproduces the vicious cycle of the women's return to the prision..

For this purpose, will be analyzed data concerning resocialization in the country, profile of incarcerated women, well as the international and national legislation does it have on right to work for people deprived of liberty. Thus, the methodology will be focus in an interdisciplinary approach, based on the hypotheticaldeductive method, using the bibliographical and documental technique and statistical data.

The work, as well as settle written as a right has evolved over time, guaranteeing women protection and equality in the labour market. However, when we analyze the reality, the wage gap highlights that gender bias exists today. In prision system, those women suffer with segregation or many times never even get a job, have their woman's condition worsened by prison. Is necessary the discussion of prison work for women, since theres is a vicious cycle of lack of resocialization, human dignity that has a consequence the return to the prison.

\section{Work, human dignity and resocialization}

Work, according to the Michaelis dictionary mean set of productive or intellectual activities exercised by man to generate utility and achieve a specific purpose. The concept and the meaning of work has evolved and as reported by Prates, has assumed the status of fundamental right after the industrial revolution, major milestone of right of second dimension, what resulted in the struggle of the proletariat for social rights((2017, p.1016).

The Constitution of the Federative Republic of Brazil (1988) in its article $1^{a}$,IV classifies work as fundamental constitutional principle in a democratic state. In the articles $5^{\circ}, \mathrm{XIII}$ and $6^{\circ}$ work is a social right for everyone and the constitution of 1988 brings as an innovation the consolidation of the right to work in this article $7^{\circ}$.

Within the framework of persons deprived of liberty, the work as law is in Nelson Mandela Rules (United Nations [UN], 1955). In this articles 71 to 76 , states that work cannot be painful, has the function of maintaining or increasing the abilities of the prisoners to make an honesty living after their freedom, besides work being remunerated and similar to normal condition of free works.

It is in Lei de Execuções Penais (law. ${ }^{\circ} 7.210,1984$ ) that work is regulated as a condition of human dignity, with educative and productive purpose, being both a duty (article $38, \mathrm{~V}$ ) and a right for prisoner( article 41,II).

Since the right to work is constituted as fundamental principle and social value, must be observed by all, including by the government. According to Prates (2017,p. 1015) is one of the most relevant social right in a view of having the objective, in addition to the promotion of human dignity, physical survival and achievement linked to the right to life, because without work there is no possibility of a life.

Therefore, the work is intrinsically linked to human dignity and enable the comprehension of man as social individual, belonging and transforming the reality that's surrounds. It's through the work that is possible a dignified life and exercise of citizenship, achieving the objectives of survival and personal fulfillment.

According to Greco $(2015$, p.65) dignity is a quality that integrates the human conditional itself, being, as a rule, indispensable and inalienable, inherent in the human being itself and therefore is a value that cannot be suppressed because of its own nature. To corroborate Sarlet (2012) defines the dignity of the human person as :

"The intrinsic and distinctive quality of every human being that makes him worthy of the same respect and consideration on the part of the State and the community. Implying, in this sense, a complex of fundamental rights and duties that ensure the person to ensure that the person is both against all degrading and inhuman acts, how they will guarantee you the minimum existential conditions for a healthy life. Besides promoting and promoting their active and coresponsible participation in the destinies of their own existence and life in communion with other human beings (p.40)"

In this sense, Greco asserts that even the most vile, the most obnoxious man, the coldest and cruelest criminal carries this value (2015,p. 65). Therefore, when committing a crime, the person does not lose any of the rights inherent in the quality of a human being, except for his freedom. The person arrested holds human dignity as well as people who have not committed crimes.

The Decree-law n ${ }^{\circ} 2.848$ of December 1940 that instituted the Código Penal Brasileiro, in the article 59 adopts the theory mixed or unifying the penalty, presenting both the retributive character, functioning as a retribution to the condemned for the execution of an offence, as well as preventive nature, a way of preventing the realization of new conflicts. It is in the preventive character that resocialization is inserted, as a way of reintegration of the prisoner into society, made through work and education.

Baratta (1990) proposes the replacement of the term "resocialization" for "reintegration", since the focus would not be the criminal as an object, would be the process of opening up prison for society and opening society to prison. According to Alvino Augusto de Sá (2013,p. 120) the reintegration of the prisoner will only be 
possible to the extent that an approximation between him and society is promoted.

The resocialization of those who are in prision it will have effectiveness by the work, since the creation of a regular habit of discipline, responsibility and reward (salary) will remove the need for continuity if they commit crimes. There will be both the reintegration of the prisoner, and the subsequent discharge to social life , participation in the conduct of a government, that is, there will be respect for its dignity and citizenship.

"It is by professionalization (skilled labor) and for economic security, for the full occupation of their time in useful and productive thing and, therefore, by the birth of reason to live, by the recognition of rights and duties, of the responsibilities and human dignity that adjustment or readjustment will be achieved.(Mirabete,2004, as cited in Ministério Público do Estado de Goiás,2011, p.18)"

Work as a fundamental right plays an important role in the effectiveness of dignity, especially when it comes to persons deprived of liberty. In the prison system, work is the bridge between society, being the main pillar of resocialization and the the only way of promoting the citizenship of the disabled without them ever committing crimes again.

\section{Women in prison and work}

As stated in last report of Infopen Mulheres, published in 2018, Brazil has a prison population of 42,355 women (Departamento Penitenciário Nacional[DEPEN],2017). In the international context, the country ranks fourth in the ranking, with a prison rate of $40.6 \%$. According to the Ong Conectas (2018), Brazil stands out in the evolution of the female imprisonment rate with an increase of $455 \%$ between 2000 and 2016 .

The majority of women, about $45 \%$, are provisional prisoners without conviction, followed by $32 \%$ in closed conditions, $16 \%$ in the semi-open and $7 \%$ in the open conditions. The spaces occupied by these women are intended exclusively for men, since only $7 \%$ are women-oriented penal establishments, on the other hand, $75 \%$ are destined for men, which highlights the gender difference in prisons.

This prison population is composed mostly of women from 18 to 29 years old, black, single(62\%). According to the Ong Conectas in partnership with the Pastoral Carcerária(2012), these women integrate vulnerability and social exclusion groups with low education level, single mothers with an average of more than two children and $95 \%$ of them have been victims of violence at some point in their lives.

In relation to schooling, $66 \%$ have not yet reached the high school having completed at most middle school. Only $15 \%$ concluded high school and $1 \%$ the college. Concerning the frequency of attempted or completed crimes among the records of women in custody in the country, it is noted that the crime of drug trafficking is the main responsible for most of the prisons, totaling 59.9\% of cases. The public defender's of the state of São Paulo Surrailly Youssef, in an interview with Revista Gama asserts:

"Many women commit crimes because they need to supplement their income to support their children, and trafficking is a flexible job that allows them to be at home to take care of them $(. .$.$) The woman plays roles of guard, transportation, retail, becoming more vulnerable to$ the overt policing of a punitive drug policy(Payno,2020)."

Women who arrive in prison make up a vulnerable class who work in the illicit market which is impregnated with sexual division of labour according to a 2017 report from ITTC (Instituto Terra, Trabalho e Cidadania) most incarcerated women were, before prison, the financial and affective core of their families (Payno,2020). Therefore, when entering the prison system with low schooling and no work perspective, being financially responsible for a family, the trend is a return to crime.

Nationally the percentage of prisoners working in Brazil reaches 18,9\% (Velasco et al.,2019), while that of women reaches $24 \%(D E P E N, 2017)$. These are works that can be performed internally, such as prison unit maintenance, bakery, cleaning, woodworking, which mostly do not come preceded by professional course that would count as experience in the external labor market.

In addition to the small amount of work available inside prisons and lack of professionalization, women who work more in prisons have their routine hampered amid the challenges of the structure of a criminal justice system aimed at men. According to Nana Queiroz (2015) in her book Presas que menstruam "the State forgets that women need tampons, for example, and they need toilet paper for two needs instead of one. Or even that women get pregnant, have children and need to breastfeed".

The author further asserts that women are forgotten by by the own prison system that treats them like men, being offered the same aid as male prisoners, ignoring the gender difference and extra needs (Queiroz,2015). So the gender difference in prisons is greater, considering the vulnerability of this prison population that doesn't have their specificities of hygiene, maternity, work and education considered and are deprived of liberty, in total abandonment.

\section{Final remarks}

The objective of this work was to discuss the issue of dignity in the workplace of women deprived of liberty, 
since the prison, system aggravates and highlights gender differences. In addition, evidenced the violation of the right to work and consequent resocialization.

The structure of the work allowed the presentation of the concepts of work as a fundamental right, human dignity and resocialization, in addition to the situation of women in the context of deprivation of liberty, which corroborate the thesis that the prison system aggravates gender differences. Moreover, the situation of imprisoned women who have no incentive to work and professionalization shows a great cycle of vulnerability of these women.

The work is segregating, and in the prison system where resocialization is minimal, non-existent, imprisoned women live in a vicious cycle of lack of human dignity, segregation. They don't have opportunities for a return to the labour market, even the insertion, when we talk about those who are mostly householders, unemployed and resort to crime, without State protection whether deprived of liberty or not.

Prison is a mere crime industry that continues to reproduce its social structures even after serving a sentence. For women who pass through gender segregation inside and outside prisons, from vulnerable groups, resocialization is minimal and the opportunity and for work outside prisons does not exist. They arrive unprepared and do not undergo efficient work incentives that empower them for the job market.

It is necessary to pay attention to gender specificities for the promotion of public policies, especially with regard to professional training, inside and outside prisons, so that these women can have a dignified return to society. For the effectiveness of resocialization whose main pillar is the work, is fundamental, according to Baratta (1990) the commitment of society to make prison less and less prison. It is only with the opening of the prison to society and society to the prison that reintegration is effective.

\section{References}

Baratta, A,(1990),Por um Concepto crítico de reintegración social del condenado. [Online] Available: http://perso.unifr.ch/derechopenal/assets/files/articulos/a_20120608_01.pdf

Brasil.(1988). Constituição da República Federativa do Brasī de 1988. (34rd ed.). Atlas S.A.

Departamento Penitenciário Nacional,(2017), Levantamento Nacional de Informações Penitenciárias: Infopen Mulheres.[Online] Available: http://antigo.depen.gov.br/DEPEN/depen/sisdepen/infopen-mulheres

Greco, R.(2015). Sistema Prisional. Colapso atual e soluções alternativas. (2rs ed.) Impetus.

Instituto Brasileiro de Geografia e Estatística, (2010), Estatísticas de Gênero-indicadores sociais das mulheres no Brasil.[Online] Available: https://www.ibge.gov.br/estatisticas/multidominio/genero/20163-estatisticasde-genero-indicadores-sociais-das-mulheres-no-brasil.html $=\& t=o$-que-e

Lei 2.848, de 7 de dezembro de 1940(1942,1 janeiro). Código Penal. Presidência da República.

Lei 5.452, de 1 de maio de 1943(1943, 9 agosto). Aprova a consolidação das Leis do Trabalho. Presidência da República.

Lei n ${ }^{\circ}$ 7.210, de 11 de julho de 1984.(1984,13 julho).Institui a Lei de Execução Penal. Presidência da República. Martinez, L.(2020). Curso de Direito do Trabalho(12rd ed.). Saraiva Educação.

Ministério Público do Estado de Goiás,(2010),Cartilha mão de obra carcerária. [Online] Available:http://www.mp.go.gov.br/portalweb/hp/7/docs/cartilha_mao_de_obra.pdf

Ong Conectas,(2012),Situação das mulheres nas prisões do Brasil: história recente.[Online] Available:https://carceraria.org.br/wp-content/uploads/2012/09/relatorio-mulheresepresas_versaofinall.pdf

Ong Conectas, (2018), Brasil é o $4^{o}$ país com mais mulheres presas no mundo. Levantamento do Ministério da Justiça aponta mais de 42 mil detentas, sendo quase a metade sem condenação. [Online] Available: https://www.conectas.org/noticias/brasil-e-o-4o-pais-com-mais-mulheres-presas-no-mundo (May 11,2018).

Payno, M, (2020) O que a sociedade perde quando uma mulher vai presa? [Online] Availbale : https:/gamarevista.com.br/special/o-que-a-sociedade-perde-quando-uma-mulher-vai-presa/ (October 3,2020)

Pesquisa Nacional por Amostra de Domicílios Contínua(2019),Mercado de Trabalho Brasileiro.[Online] Available:

https://agenciadenoticias.ibge.gov.br/media/com_mediaibge/arquivos/8ff41004968ad36306430c82eece317 3.pdf

Prates, D. O. S.(2016). O Direito Fundamental ao Trabalho no Estado Democrático de Direito. [Online] Available: https://revista.univem.edu.br/1simposioconst/article/view/1235

United Nations Development Programme -UNDP (2019). Human Development Report 2019 Beyond income, beyond averages, beyond today: Inequalities in human development in the 21st century [Online] Available: http://hdr.undp.org/en/2019-report

Queiroz, N.(2015). Presos que menstruam (13rd ed.). Editora Record.

Sá, A. A.(2013). Criminologia clínica e psicologia criminal. (3rd ed.). São Paulo: Revista dos Tribunais, (Chapters 2 and 4). 
Sarlet, I. W.(2012). Dignidade da pessoa humana e direitos fundamentais na Constituição Federal de 1988.Livraria do Advogado.

United Nations-UN, (1990), Mandela Rules [Online] Available: https://www.unodc.org/documents/justice-andprison-reform/Nelson_Mandela_Rules-E-ebook.pdf

Velasco, C., Reis, T., Carvalho, B., Leite, C., Prado, G. \& Ramalho, G.(2019). Menos de 1/5 dos presos trabalham Brasil; $1 \mathrm{em}$ cada oito estuda. [Online] Available: https://g1.globo.com/monitor-daviolencia/noticia/2019/04/26/menos-de-15-do-presos-trabalha-no-brasil-1-em-cada-8-estuda.ghtml. 